\title{
Use of EPR Spectra Peculiarities of Transition Metal lons When Studying Salt Concentrating Depending on Freezing Conditions
}

Реферат: Исследованы спектры ЭПР замороженных растворов солей парамагнитных катионов. Показано, что структура и форма спектров зависят от режима и состава среды замораживания. Полученные экспериментальные спектры ЭПР теоретически описаны спиновым гамильтонианом, содержащим аксиально-симметричный терм тонкой структуры с проявлением запрещенных $\Delta m= \pm 1$ переходов. Предложено использовать подходы ЭПР при разработке низкотемпературных технологий консервирования биологических объектов для анализа режимов замораживания и возможных криопротекторов с целью прогнозирования минимизации эффектов криоповреждений высокими концентрациями солей при замораживании.

Ключевые слова: замораживание, гиперконцентрирование, электронный парамагнитный резонанс, спин-гамильтониан, структура спектров.

Реферат: Досліджено спектри ЕПР заморожених розчинів солей парамагнітних катіонів. Показано, що структура й форма спектрів залежать від режиму та складу середовища заморожування. Отримані експериментальні спектри ЕПР теоретично описані спіновими гамільтоніаном, який містить аксіально-симетричний терм тонкої структури 3 проявом заборонених $\Delta m= \pm 1$ переходів. Запропоновано використовувати підходи ЕПР при розробці низькотемпературних технологій консервування біологічних об'єктів для аналізу режимів заморожування й можливих кріопротекторів із метою прогнозування мінімізації ефректів кріопошкоджень високими концентраціями солей при заморожуванні.

Ключові слова: заморожування, гіперконцентрування, електронний парамагнітний резонанс, спін-гамільтоніан, структура спектрів.

Abstract: The EPR spectra of frozen salt solutions of paramagnetic cations were studied. The spectra structure and shape were demonstrated to be dependent on regimen and composition of freezing medium. The obtained experimental EPR spectra are theoretically described by spin Hamiltonian containing axially symmetric term of fine structure with manifestation of forbidden $\Delta m= \pm 1$ transitions. There was proposed to use EPR approaches in designing low temperature technologies for biological object preservation to analyze freezing regimens and possible cryoprotectants to forecast the minimization of cryoinjury effects with high salt concentrations during freezing.

Key words: freezing, hyperconcentration, electron paramagnetic resonance, spin Hamiltonian, structure of spectra.

Еще на ранних этапах развития криобиологии исследователи обращали внимание на то, что повреждение биологических объектов при замораживании возникает вследствие повышения концентрации солей, метаболитов и других веществ, растворенных вне и внутри клетки, при фазовом переходе жидкой воды в твердое состояние. Эти наблюдения легли в основу концепции J.I. Lovelock, который установил, что увеличение концентрации хлорида натрия во внеклеточной среде выше 0,8 моль/л приводит к повреждению клеток [19,20], утрате мембранами клеток части фосфолипидов и холестерина, что резко снижает их устойчивость. Повреждение клеток J.I. Lovelock объяснял лио-

Отдел криобиофизики, Институт проблем криобиологии и криомедицины НАН Украины, г. Харьков

Адрес для корреспонденции:

ул. Переяславская, 23, г. Харьков, Украина 61015;

тел.: (+38 057) 373-31-41, факс: (+38 057) 373-30-84, электронная почта: olnard@mail.ru

Поступила 23.04.2013

Принята в печать 02.07.2014

Проблемы криобиологии и криомедицины. - 2014. -Т. 24, №3. -С. 212-221. (C) 2014 Институт проблем криобиологии и криомедицины НАН Украины
Even at early stages of cryobiology development the scientists paid their attention to the injury of biological objects during freezing as occurred due to a rise in concentrations of salts, metabolites and other substances, dissolved outside and inside a cell, during phase transition of liquid water into a solid state. These observations formed the basis of Lovelock's concept, which established the fact, that the augmentation of sodium chloride concentration in extracellular medium higher than $0.8 \mathrm{~mol} / 1$ resulted in cell damage $[8,9]$, a loss by cell membranes of a part of phospholipids and cholesterol, that sharply reduced their resistance. J.I. Lovelock has explained a cell damage by a lyotropic effect of saline solutions, but their protection has done by

Department of Cryobiophysics, Institute for Problems of Cryobiology and Cryomedicine of the National Academy of Sciences of Ukraine, Kharkov, Ukraine

Address for correspondence:

23, Pereyaslavskaya str., Kharkov, Ukraine 61015;

tel.:+380 57373 3141, fax: +380 57373 3084,

e-mail: olnard@mail.ru

Received April, 23, 2013

Accepted July, 02, 2014

Probl. Cryobiol. Cryomed. 2014. 24(3): 212-221.

(C) 2014 Institute for Problems of Cryobiology and Cryomedicine 
тропным эффектом солевых растворов, а их защиту - коллигативными свойствами криопротекторов (действием, связанным со снижением концентрации солей при данной отрицательной температуре). Считается, что криоповреждения биообъектов повышенными концентрациями солей при замораживании играют значительную роль при низких скоростях замораживания [21]. Эти закономерности и другие экспериментальные факты объяснила двухфакторная гипотеза криоповреждения P. Mazur. В основе гипотезы и ее физико-математической модели [22, 23], нашедшей дальнейшее развитие в работах О.M. Silvares [28] и Е.А. Гордиенко [8], лежит предположение, что одним из явлений, которые приводят к криоповреждениям, относится концентрирование внеклеточных растворов солей и метаболитов, изменение $\mathrm{pH}$ и ионной силы растворов. Установлено повреждающее действие повышенных концентраций солей и в растворах белков $[12,15,26,27]$. Теоретическое и практическое значение гиперконцентрационной теории криоповреждений J.I. Lovelock состоит в том, что результаты изучения механизмов влияния концентрированных растворов на клетки в условиях низких температур дают возможность обосновать защитное действие глицерина и других криопротекторов, заключающееся в снижении концентрации активного раствора путем «разбавления», особенно в зоне эвтектических температур. Вклад в построение теории криозащиты от возникающих гиперконцентраций солей внесли также исследования, проведенные в ИПКиК НАН Украины, по изучению взаимодействий криопротекторов с ионами солей $[11,12,24]$. Было показано, что катионы металлов способны образовывать комплексные соединения, в состав первой координационной сферы которых могут входить молекулы криопротекторов, аминокислоты и противоионы. Учитывая значимость повышения концентрации солей в криоповреждениях биообъектов, можно утверждать, что важной задачей при низкотемпературном консервировании является выбор среды и режимов замораживания, минимизирующих эффект гиперконцентрации. Кроме того, необходимо учитывать уровень такого концентрирования. При разработке способов и технологий криоконсервирования биологических объектов в солевых средах часто важны прогноз и предсказание степени концентрирования солей и повреждения самих биообъектов. Эти процессы косвенно можно оценить такими методическими подходами, как криомикроскопия или рентгенография, по анализу процессов кристаллизации, но методы прямого контроля степени концентрирования солей colligative properties of cryoprotectants (the action, associated with a decrease in salt concentration at a fixed negative temperature). One considers the cryoinjuries in bioobjects with the increased salt concentrations during freezing to play a considerable role under low freezing rates [10]. These regularities and other experimental facts were explained by Mazur's twofactor hypothesis for cryoinjury. The hypothesis and its physical and mathematical model [11, 12], further developed in the works of O.M. Silvares [23] and E.A. Gordienko [5] start from assumption that the concentration of extracellular solutions of salts and metabolites, change in $\mathrm{pH}$ and ionic strength of solution are referred to the one of phenomena resulting in cryoinjuries. Damaging effect of increased salt concentrations was established in protein solutions as well $[16,19,20$, 21]. Theoretical and practical importance of Lovelock's hyperconcentration theory of cryoinjuries consists in the fact that the results of studying the effect mechanisms of concentrated solutions onto the cells under low temperatures enable the substantiation of a protective effect of glycerol and other cryoprotectants, consisting in a decreased concentration of active solution via 'dilution', especially in the area of eutectic temperatures. The research performed at the Institute for Problems of Cryobiology and Cryomedicine of the National Academy of Sciences of Ukraine on studying the interactions of cryoprotectants with salt ions also contributed into the derivation of theory for cryoprotection against occurring salt hyperconcentrations $[13,14,16]$. Metal cations were demonstrated as capable to form complex compounds, the composition of first coordination sphere of which may comprise cryoprotectant molecules, aminoacids and counter-ions. Taking into account the importance of salt concentration increase in bioobject cryoinjuries we may state that the selection of medium and freezing regimens, which minimize the hyperconcentration effect, is an important task in low temperature preservation. In addition the level of such a concentration should be considered. When developing the ways and technologies for biological object cryopreservation in saline media, of importance are often the prognosis and forecasting of the degree of salt concentration and injuries in bioobjects themselves. These processes may be indirectly estimated by such methodical approaches as cryomicroscopy or X-ray diffraction, analysis of crystallization processes, but of some advantages are the methods of direct control (e.g. EPR) for salt concentration degree during freezing.

Accordingly this research aim was to study the spectra features of electron paramagnetic resonance (EPR) of transition metal ions for assessing the concentration effects during freezing. 
при замораживании (например, ЭПР) имеют ряд преимуществ.

В связи с этим целью данной работы было исследование особенностей спектров электронного парамагнитного резонанса (ЭПР) ионов переходных металлов для оценки концентрационных эффектов при замораживании.

\section{Материалы и методы}

$\mathrm{B}$ работе использовали соли $\mathrm{MnCl}_{2}$ и $\mathrm{Cu}\left(\mathrm{NO}_{3}\right)_{2}$ квалификации «ч.д.а.», которые предварительно обезвоживали высушиванием. Обезвоживанию при $105^{\circ} \mathrm{C}$ и нормальном давлении также подвергался полиэтиленгликоль. Концентрацию катионов определяли комплекснометрическим титрованием раствором ЭДТА [16]. Ошибка при определении концентрации не должна превышать $2 \%$.

Спектры ЭПР регистрировали на спектрометре «Bruker» ER 100D (Германия) со стандартной температурной приставкой. Развертка магнитного поля составляла 1000 Гс, постоянная времени при записи спектров - 0,3 с, время развертки - 100 с. Контрольные опыты показали, что при описанных условиях спектры не искажались в результате перемодуляции или инерционных эффектов.

Медленное замораживание образцов осуществляли со средними скоростями 20-35 град/мин непосредственно в резонаторе спектрометра. Образцы помещали в стеклянные капилляры с внутренним диаметром 500 нм и объемом 0,1 мл. Быстрое замораживание проводили также в резонаторе спектрометра в специальном криостате, охлаждая отдельные капли исследуемого раствора в сжиженном азоте с оценочной скоростью 1000 град/мин [9].

\section{Результаты и обсуждение}

Важным физико-химическим фактором при замораживании биологического материала является повышение концентрации электролитов при охлаждении в результате фазового перехода воды из жидкого состояния в твердое. Особенно резко концентрация электролитов увеличивается в зоне эвтектических температур [13], что приводит к нарушению конформации биомакромолекул и структуры клеточных мембран.

Учитывая, что спектры ЭПР солей парамагнитных катионов чувствительны к изменениям в ближайшем окружении этих ионов [7, 10, 25], их целесообразно использовать для оценки концентрирования солей, в том числе и при разных условиях замораживания. «Прозрачность» замороженных растворов для излучений в СВЧ диапазоне позволяет применять этот метод для анализа структуры,

\section{Materials and methods}

We used $\mathrm{MnCl}_{2}$ and $\mathrm{Cu}\left(\mathrm{NO}_{3}\right)_{2}$ salts of analytical pure grade, preliminarily dehydrated with drying. Polyethylene glycol underwent dehydration at $105^{\circ} \mathrm{C}$ and normal pressure as well. The cation concentration was determined by complexometric titration with EDTA solution [22]. The error in concentration determining should not exceed $2 \%$.

EPR spectra were recorded with Bruker ER 100D (Germany) with the standard temperature adapter. Scanning of magnetic field was $1000 \mathrm{Gs}$, the time constant at spectra recording was $0.3 \mathrm{sec}$, and $200 \mathrm{sec}$ scanning time. Control experiments demonstrated that under described conditions the spectra remained undistorted as a result of overmodulation or inertial effects.

Samples were slowly frozen with $20-35 \mathrm{deg} / \mathrm{min}$ average rates in spectrometer resonator. Samples were placed into $0.1 \mathrm{ml}$ glass capillaries with $500 \mathrm{~nm}$ inner diameter. Rapid freezing was carried-out in spectrometer resonator as well in a special cryostat by cooling single drops of studied solution in a liquefied nitrogen with evaluating rate of $\sim 1000 \mathrm{deg} / \mathrm{min}$ [6].

\section{Results and discussion}

An increase in electrolyte concentration during cooling as a result of water phase transition from a liquid state into solid one is an important physical and chemical factor in biological material freezing. Electrolyte concentration augments especially sharply in the area of eutectic temperatures [17], that leads to a disorder in biomacromolecule conformation and cell membrane structure.

Taking into account the fact, that the EPR spectra of paramagnetic cation salts are sensitive to changes in the surrounding vicinity of these ions $[4,7,15]$ it is expedient to use them for estimating salt concentration, including when applying different freezing conditions as well. The 'transparence' of frozen solutions for radiation in microwave spectrum enables applying this method to analyze the structure, phase state and molecular-dynamic features of frozen solutions in ice phase presence $[16,27,28]$.

For example, the manganese ions $\left(\mathrm{Mn}^{2+}\right)$ in diluted aqueous solution have EPR spectrum with six-component hyperfine structure. Under slow cooling down of aqueous solutions and water transition from a liquid state into solid one, in a residuary liquid phase of solvent the high local concentrations of paramagnetic cations are formed, the distance between them reduces, resulting in strengthening of spin-spin interactions between paramagnetics and a change in EPR spectrum form. When decreasing the temperature down to the values of solidification of eutectic liquid ranges with dissolved substance the EPR linewidth (according to the theory 
фазового состояния и молекулярно-динамических свойств замороженных растворов в присутствии фазы льда $[4,5,12]$.

Например, ионы марганца $\left(\mathrm{Mn}^{2+}\right)$ в разбавленном водном растворе имеют спектр ЭПР с шестикомпонентной сверхтонкой структурой. При медленном охлаждении водных растворов и переходе воды из жидкого в твердое состояние в оставшейся жидкой фазе растворителя образуются высокие локальные концентрации парамагнитных катионов, уменьшается расстояние между ними и в итоге усиливаются спин-спиновые взаимодействия между парамагнетиками и изменяется вид спектра ЭПР. При понижении температуры до значений затвердевания эвтектических жидких областей с растворенным веществом ширина линии ЭПР (согласно теории межмолекулярных взаимодействий в твердом теле) перестает зависеть от дальнейшего понижения температуры. На рис. 1, А приведен спектр водного раствора $\mathrm{MnCl}_{2}$, медленно замороженного в резонаторе спектрометра. Вместо сверхтонкого секстета, характерного для водного раствора соли в жидком состоянии, наблюдается широкий синглет с $\Delta H \sim 550$ Гс. Отсутствие сверхтонкой структуры в этом случае свидетельствует о значительных межмолекулярных взаимодействиях в системе, обусловленных высокими концентрациями ионов [1]. При быстром замораживании, когда образуется мелкокристаллическая твердая структура с вкраплениями аморфной фазы, а межмолекулярные эффекты проявляются в меньшей степени, в спектре ЭПР наблюдается суперпозиция секстета с синглетом (рис.1, В). Об улучшении растворения магнетика свидетельствует появление сверхтонкой структуры в спектрах ЭПР $\mathrm{Mn}^{55}$. Использование специальных подходов при замораживании солевых растворов позволяет получать твердую матрицу без значительных локальных концентраций солей, что подтверждается высоким разрешением спектров ЭПР таких образцов. Так, например, для предотвращения концентрирования парамагнетиков при охлаждении водных растворов было предложено насыщать раствором соли полидекстрановый гель [18]. В этом случае после замораживания были получены спектры ЭПР с высоким разрешением.

Проведенные нами исследования водно-гликолевых растворов $\mathrm{MnCl}_{2}$ показали, что при содержании в них $(0,15-0,35)$ М гликоля после медленного охлаждения до $-180^{\circ} \mathrm{C}$ наблюдается лучшее разрешение спектра ЭПР, даже по сравнению с быстро замороженными водными растворами. При этом с понижением температуры происходит постепенное «вымораживание» воды и увеличивается of intermolecular interactions in a solid body) stops to be dependent on further temperature decrease. The Fig. 1 A demonstrates the spectrum of $\mathrm{MnCl}_{2}$ aqueous solution slowly frozen in spectrometer resonator. Instead of a hyperfine sextet, being typical for aqueous saline solution in a liquid state we observe a wide singlet with $\Delta H \sim 550 \mathrm{Hs}$. Absence of hyperfine structure in this case testifies to significant molecular interactions in the system, stipulated by high-concentrated ions [24]. During rapid freezing when a small-crystal solid structure with inclusions of amorphous phase is formed and intermolecular effects are manifested in less extent, the superposition of sextet with singlet is observed in EPR spectrum (Fig. 1B). The occurrence of hyperfine structure in $\mathrm{Mn}^{55}$ EPR spectra testifies to the improvement of magnet dissolution. The use of special approaches in freezing saline solutions enables to obtain a solid matrix with no significant local salt concentrations, that is confirmed by a high resolution of EPR spectra of these samples. Thus, for example, in order to prevent the paramagnet concentration when cooling aqueous solutions there was proposed to saturate polydextran gel with salt solution [2]. In this case after freezing we obtained high resolution EPR spectra.

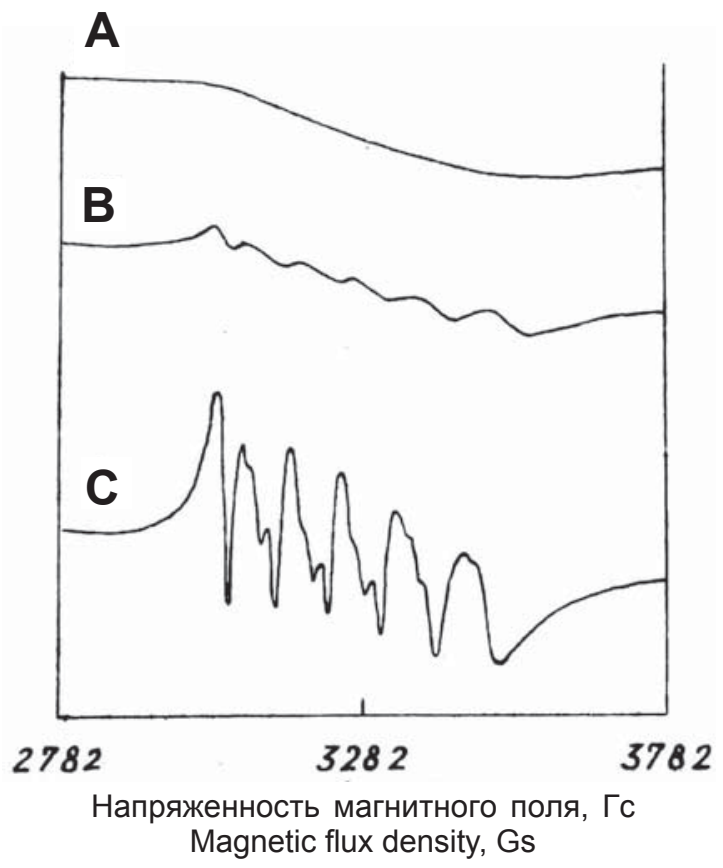

Рис. 1. Спектры ЭПР 0,01 М растворов $\mathrm{MnCl}_{2}$ : А - водный раствор (медленное замораживание); В - водный раствор (быстрое замораживание); С - водно-полиэтиленгликолевый раствор, содержащий 2,8 М ПЭГ-300 (медленное замораживание).

Fig. 1. EPR spectra of $0.01 \mathrm{M} \mathrm{MnCl}_{2}$ solutions: $\mathbf{A}$ - aqueous solution (slow freezing); $\mathbf{B}$ - aqueous solution (rapid freezing); $\mathbf{C}$-aqueous-polyethylene glycol solution, containing 2.8 M PEG-300 (slow freezing). 
концентрация гликоля в оставшейся жидкой фазе до эвтектических ее значений. Ионы, сольватированные молекулами гликоля, не претерпевали такого концентрирования и сближения между собой, как в водных растворах, в которых по виду спектров ЭПР отмечалось значительное спин-спиновое взаимодействие. И это происходило несмотря на то, что такое содержание гликолей в водном растворе при замораживании сохраняет кристаллизацию достаточно крупных зерен льда [14]. Существует предположение, что аквакомплексы могут в таких системах внедряться в полости структурных образований гликолей [12]. Использование нами высоких концентраций полиэтиленгликоля (близких к эвтектическим) позволило даже в случае медленного замораживания получить твердую фазу, сходную с аморфной структурой. В спектрах ЭПР твердых образцов водно-полиэтиленгликолевых растворов $\mathrm{MnCl}_{2}$ в этом случае наблюдалось высокое разрешение сверхтонких переходов, включая и «запрещенные» (рис. 1, С).

Использование в качестве добавок других органических растворителей, например этилового спирта, также предотвращало концентрирование солей при замораживании, а в низкотемпературных $\left(-180^{\circ} \mathrm{C}\right)$ спектрах ЭПР таких растворов $\mathrm{MnCl}_{2}$ наблюдалось сверхтонкое расщепление, свидетельствующее об уменьшении спин-спиновых взаимодействий между отдельными катионами.

Сверхтонкая структура спектра ЭПР 0,01 М $\mathrm{MnCl}_{2}$ замороженного водно-полиэтиленгликолевого раствора (рис. 1, С) сходна со сверхтонкой структурой низкотемпературных спектров ЭПР растворов соли в метаноле [6]. Указанные спектры состоят из шести «главных» линий со значением $g=2,00$ и расстояниями между ними (90-100) Гс. Помимо «главных», в спектрах наблюдаются и другие линии с достаточно хорошим разрешением, которые состоят из пяти дублетов. Каждый дублет расположен между двумя «главными» линиями. Расщепление между двумя линиями, составляющими дублет, находится в пределах 20-30 Гс (таблица). Дублет в высокопольном конце имеет более слабую интенсивность. Шесть главных линий могут быть описаны спиновым гамильтонианом, который включает сферически симметричный терм сверхтонкой структуры и не содержит терм тонкой структуры. Эти линии также могут быть описаны спиновым гамильтонианом, содержащим аксиально-симметричный терм тонкой структуры с единственным переходом при изменении магнитного квантового числа электронного спина: $M=1 / 2-M=-1 / 2$ [17].

Для последнего случая спиновый гамильтониан имеет вид:
Our studies of aqueous-glycol $\mathrm{MnCl}_{2}$ solutions demonstrated that when glycol content in them was even $(0.15-0.35) \mathrm{M}$, after slow cooling down to $-180^{\circ} \mathrm{C}$ there was observed a higher resolution of EPR spectrum if comparing with rapidly frozen aqueous solutions. In this case with temperature decrease a gradual water 'freezing-out' occurs and glycol concentration in remaining liquid phase increases up to its eutectic values. The glycol molecules solvated with ions did not undergo such a concentration and approach between themselves as it was in aqueous solutions, where by EPR spectra shape we noted a significant spin-spin interaction. This occurred despite the fact that such a content of glycols in aqueous solution in freezing kept the crystallization of quite large ice grains [18]. There is an assumption that the aquacomplexes in such systems may penetrate into the cavities of structural formations of glycols [16]. High concentrations of polyethylene glycol (close to eutectic ones) we used allowed even at slow freezing to obtain a solid phase close to amorphous structure. In EPR spectra of solid samples of $\mathrm{MnCl}_{2}$ aqueous-polyethylene glycol solutions in this case we noted a high resolution of hyperfine transitions, including 'forbidden' ones too (Fig. 1C).

The use as additives of other organic solvents, ethyl alcohol for example, also prevented salt concentration in freezing, but in low temperature $\left(-180^{\circ} \mathrm{C}\right) \mathrm{EPR}$ spectra of such $\mathrm{MnCl}_{2}$ solutions we observed a hyperfine splitting, testifying to a decrease in spin-spin interactions between certain cations.

The EPR spectra hyperfine structure of $0.01 \mathrm{M}$ $\mathrm{MnCl}_{2}$ of frozen aqueous-polyethylene glycol solution (Fig. 1C) is similar to that of low temperature EPR spectra of salt solutions in methanol [3]. The mentioned spectra comprise 6 'principal' lines with value of $g=2.00$ and distances between them (90-100) Gs. In addition to 'principal' lines, the other ones with quite good resolution, consisting of five doublets, are observed in spectra. Each doublet is located between two 'principal' lines. The splitting between two lines, forming doublet is within the limits of 20-30 Gs (Table). The doublet in a high field terminal has a weaker intensity. Six principal lines may be described with spin Hamiltonian, which comprises a spherically symmetric term of hyperfine structure and contains no term of fine structure. These lines may be also described with spin Hamiltonian, containing axial-symmetric term of fine structure with a single transition when changing magnetic quantum number of electron spin: $M=1 / 2-$ $M=-1 / 2[1]$.

For the latter case the spin Hamiltonian is as follows:

$$
\hat{H}=g \beta H S+D\left\{S_{z}^{2}-\frac{1}{3} S(S+1)\right\}+A S I
$$




$$
\hat{H}=g \beta H S+D\left\{S_{z}^{2}-\frac{1}{3} S(S+1)\right\}+A S I,
$$

где $g$ - фактор спектроскопического расщепления; $\beta$ - электронный магнетон Бора; $H$ - вектор постоянного магнитного поля; $\mathrm{S}$ - вектор спинового углового момента электрона; $D$ - константа спингамильтониана; $A$ - константа сверхтонкого магнитного взаимодействия; $I-$ вектор спинового углового момента ядра.

Положение главных линий определяется выражением:

$$
H=\frac{h \gamma_{0}}{g \beta}-A m-\frac{A^{2}}{2} \frac{g \beta}{h \gamma_{0}}\left[I(I-1)-m^{2}\right]-\frac{A^{2}}{2} \frac{g \beta}{h \gamma_{0}} m(2 m-1),
$$

где $h$ - постоянная Планка; $\gamma_{0}$ - гиромагнитное отношение для электрона; $m$ - ядерное магнитное квантовое число.

Из этого выражения видно, что с гамильтонианом, содержащим аксиально-симметричный терм тонкой структуры, расщепление между «главными» линиями должно увеличиваться с возрастанием магнитного поля.

Сравнивая теоретически предсказываемый спектр ЭПР с экспериментально полученным (рис. 1, С), можно утверждать, что шесть «главных» линий являются сверхтонкими компонентами от ядра марганца с магнитным моментом $\mu=3,4611$ и спином $I=5 / 2$. Пары слабоинтенсивных линий между «главными» компонентами обусловлены переходами с одновременно изменяющимися спинами электрона и ядра на \pm 1 . Была предпринята попытка проанализировать запрещенные переходы спектров сверхтонкой структуры ЭПР в замороженных стеклообразных и поликристаллических состояниях $[6,17,18]$. Положение спектральных линий для запрещенного перехода можно представить следующим образом [17]:

$$
\begin{aligned}
& \text { для }|1 / 2, m+1\rangle \leftrightarrow|-1 / 2, m\rangle \\
& \begin{aligned}
H & =H_{0}-A\left(m+\frac{1}{2}\right)+\left(A^{2} / 2 H_{0}\right)\left[m(m+1)+\frac{1}{4}\right] ;
\end{aligned} \\
& \text { для }|1 / 2, m\rangle \leftrightarrow|-1 / 2, m+1\rangle \\
& H=H_{0}-A\left(m+\frac{1}{2}\right)+\left(A^{2} / 2 H_{0}\right)\left[m(m+1)-\frac{67}{4}\right] .
\end{aligned}
$$

В уравнениях (1) и (2) $H_{0}=h \gamma / g \beta$. При $I=5 / 2$ (для ионов марганца) приведенные выше выражения определяют пять дублетов, каждый из которых расположен на половине расстояния между двумя разрешенными линиями сверхтонкой структуры. where $g$ is spectroscopic splitting factor; $\beta$ is Bohr electron magneton; $H$-constant magnetic field vector; $S-$ vector of spin angular momentum of electron; $D-$ spin Hamiltonian constant; $A$ - constant of hyperfine magnetic interaction; $I$ - vector of spin angular momentum of nucleus.

The position of principal lines is determined by the expression:

$$
H=\frac{h \gamma_{0}}{g \beta}-A m-\frac{A^{2}}{2} \frac{g \beta}{h \gamma_{0}}\left[I(I-1)-m^{2}\right]-\frac{A^{2}}{2} \frac{g \beta}{h \gamma_{0}} m(2 m-1),
$$

where $h$ is Planck's constant; $\gamma_{0}-$ gyromagnetic ratio for electron; $m$ - nuclear magnetic quantum number.

This expression shows that with Hamiltonian, comprising axial-symmetric term of fine structure the splitting between 'principal' lines should augment with magnetic field increase.

When comparing the theoretically predicted EPR spectrum with experimentally obtained one (Fig. 1, c) we may state that six 'principal' lines are the hyperfine components from manganese nucleus with magnetic momentum $\mu=3.4611$ and spin $\mathrm{I}=5 / 2$. The pairs of low-intensity lines between 'principal' components are stipulated by transitions with simultaneously changing spins of electron and nucleus by \pm 1 . An attempt was made to analyze the forbidden transitions of EPR hyperfine structure spectra in frozen vitreous and polycrystal states [1-3]. The position of spectral lines for forbidden transition can be presented as follows:

$$
\begin{aligned}
& \text { for }|1 / 2, m+1\rangle \leftrightarrow|-1 / 2, m\rangle \\
& \qquad \begin{array}{l}
H=H_{0}-A\left(m+\frac{1}{2}\right)+\left(A^{2} / 2 H_{0}\right)\left[m(m+1)+\frac{1}{4}\right] \\
\text { for }|1 / 2, m\rangle \leftrightarrow|-1 / 2, m+1\rangle \\
H=H_{0}-A\left(m+\frac{1}{2}\right)+\left(A^{2} / 2 H_{0}\right)\left[m(m+1)-\frac{67}{4}\right]
\end{array}
\end{aligned}
$$

In equations (1) and (2) $H_{0}=h \gamma / g \beta$. At $I=5 / 2$ (for manganese ions) the mentioned above expressions determine five doublets, each of them is located at halfway between two resolved lines of hyperfine structure. By the equations (1) and (2) we may calculate the splitting $\Delta H$ for the doublet:

$$
\Delta H=17 A^{2} / 2 H_{0} .
$$

Fig. 1C shows the EPR spectrum structure to coincide well with the calculated one (proceeding from corresponding Hamiltonian). If measuring A from the positions of 'principal' lines, the $\Delta H$ value can be approximately calculated and compared with the measured values of doublet splittings. The results of comparison 


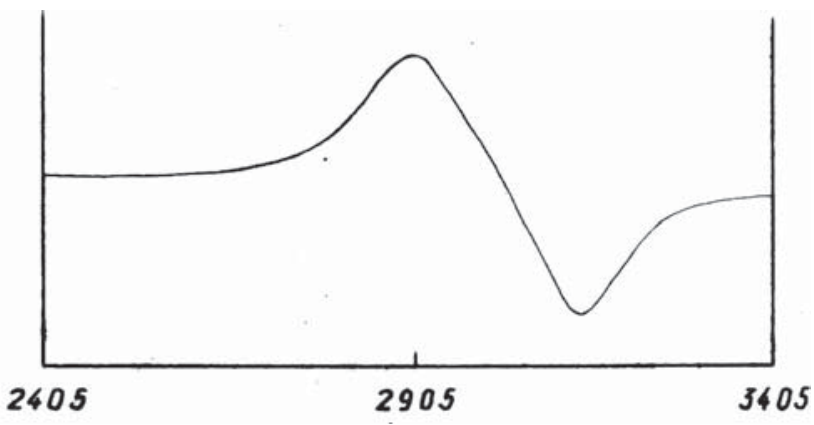

Напряженность магнитного поля, Гс Magnetic flux density, Gs

Рис. 2. Спектр ЭПР для $0,01 \mathrm{M}$ водного раствора $\mathrm{Cu}\left(\mathrm{NO}_{3}\right)_{2}$, медленно замороженного до температуры $-180^{\circ} \mathrm{C}$.

Fig. 2. EPR spectrum for $0.01 \mathrm{M}$ aqueous solution $\mathrm{Cu}\left(\mathrm{NO}_{3}\right)_{2}$ slowly frozen down to $-180^{\circ} \mathrm{C}$.

По уравнениям (1) и (2) можно вычислить расщепление $\Delta H$ для дублета:

$$
\Delta H=17 A^{2} / 2 H_{0} .
$$

Структура спектра ЭПР, представленная на на рис. 1, С, хорошо совпадает с рассчитанной (исходя из соответствующего гамильтониана). Если измерить $A$ из положений «главных» линий, то можно приблизительно рассчитать величину $\Delta H$ и сопоставить с измеренными значениями расщеплений дублета. Результаты сравнения, приведенные в таблице, показывают хорошее совпадение этих величин.

Аналогичные данные можно получить и для растворов солей других парамагнитных катионов. Так, на рис. 2 представлен спектр ЭПР медленно замороженного водного раствора $\mathrm{Cu}\left(\mathrm{NO}_{3}\right)_{2}$, который состоит из симметричной синглетной линии, не имеющей сверхтонкой структуры. Это обусловлено наличием межчастичных диполь-дипольных взаимодействий эквивалентных спинов, вызванных концентрированием соли при замораживании и сближением при этом парамагнитных ионов, что и приводит к свертыванию сверхтонкой структуры. После использования такого же режима замораживания водно-полиэтиленгликолевого раствора этой соли в спектре ЭПР ионов $\mathrm{Cu}^{2+}$ наблюдается значительно лучшее разрешение спектра ЭПР с проявлением сверхтонкой структуры (рис. 3), что свидетельствует об отсутствии концентрирования солей при замораживании. Полученные спектры также можно описать спин-гамильтонианом, подобным приведенному выше. Проявление при этом сверхтонкой структуры спектра позволяет рассчитать даже энергию связи с ближайшими лигандами. given in the Table demonstrate a good matching of these values.

The similar data may be obtained for salt solutions of other paramagnetic cations as well. Fig. 2 shows the EPR spectrum of slowly frozen $\mathrm{Cu}\left(\mathrm{NO}_{3}\right)_{2}$ aqueous solution, consisting in symmetric singlet line without hyperfine structure, that is stipulated by the presence of interparticle dipole-dipole interactions of equivalent spins, caused by salt concentration during freezing and approaching of paramagnetic ions, that results in contraction of hyperfine structure. After using a similar freezing regimen of aqueous-polyethylene glycol solution of this salt in EPR spectrum of $\mathrm{Cu}^{2+}$ ions there is observed a much higher resolution of EPR spectrum with manifestation of hyperfine structure (Fig, 3), that testifies to the absence of salt concentration during freezing. The obtained spectra may be also described by spin-Hamiltonian similar to the mentioned above one. In this case the manifestation of hyperfine structure of spectrum enables to calculate even the bond energy with the nearest ligands. In our case, the EPR spectra parameters were used to assess the degree of covalency of ligand $\sigma$-bonds in the $x y$ plane of squareplanar copper complexes, e. $g$. with formazans [26] or cryoprotectant molecules [13].

As it proceeds from the mentioned above experimental data the use of EPR method allows to differ the isolated and interacting paramagnetic ions. Molecular interactions in aqueous solutions are determined by the structure of the nearest environment of cations and solution in a whole. In the cations besides the first hydration shell we noted the presence of resistant se-

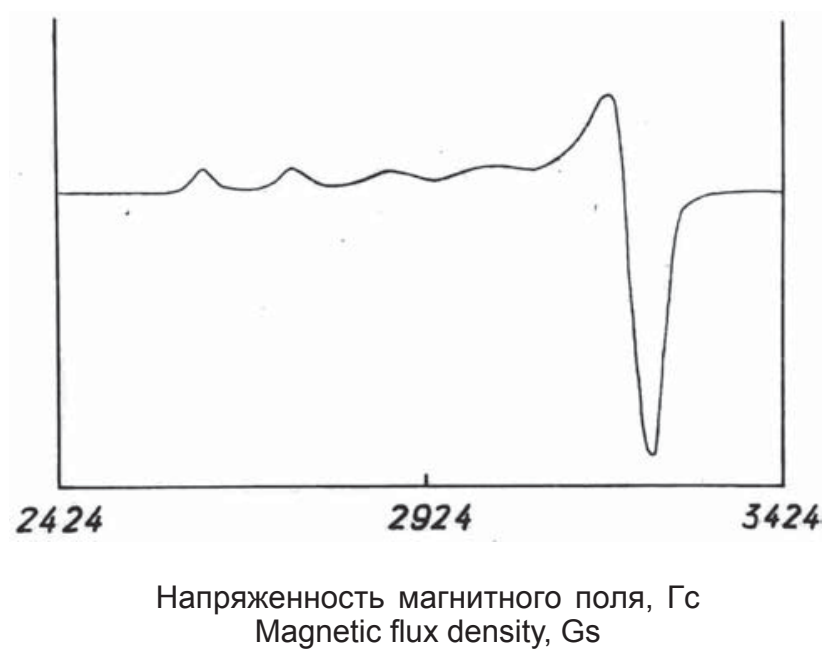

Рис. 3. Спектр ЭПР для 0,01 М водно-полиэтиленгликолевого раствора $\mathrm{Cu}\left(\mathrm{NO}_{3}\right)_{2}$, медленно замороженного до температуры $-180^{\circ} \mathrm{C}$.

Fig. 3. EPR spectrum for $0.01 \mathrm{M}$ aqueous-polyethylene glycol solution $\mathrm{Cu}\left(\mathrm{NO}_{3}\right)_{2}$ slowly frozen down to $-180^{\circ} \mathrm{C}$. 
Так, по параметрам спектров ЭПР была оценена степень ковалентности $\sigma$-связей лигандов в плоскости $x y$ плоскоквадратных комплексов меди, например, с формазанами [3] или молекулами криопротекторов [24].

Как следует из приведенных выше экспериментальных данных, использование метода ЭПР дает возможность различать изолированные и взаимодействующие друг с другом парамагнитные ионы. Межмолекулярные связи в водных растворах солей определяются структурой ближайшего окружения катионов и раствора в целом. У катионов отмечено наличие, помимо первой гидратной оболочки, устойчивой второй, а также возможное существование последующих гидратных сфер, устойчивость которых уменьшается по мере увеличения их числа [2]. Наличие такой гидратной шубы в сильно разбавленных растворах препятствует сближению катионов на достаточно близкие расстояния, что снижает эффективность межмолекулярных взаимодействий. При этом форма спектров ЭПР определяется в основном релаксационными эффектами в жидких системах, и в пределах концентрации соли от 0,001 до 0,1 практически не зависит от разведения. При замораживании водных растворов солей в результате концентрирования соли в оставшихся жидких областях усиливаются межмолекулярные спин-спиновые взаимодействия, которые модулируются до полного затвердевания системы поступательным движением частиц жидкости. Такое усиление межмолекулярных взаимодействий между парамагнитными центрами приводит к значительному изменению спектров ЭПР. В замороженных водно-полиэтиленгликолевых растворах солей в спектре ЭПР проявляются тонкая и сверхтонкая структуры, что свидетельствует о значительном уменьшении диполь-дипольных взаимодействий между парамагнитными центрами из-за большого расстояния между ними в твердой матрице. Уменьшению взаимодействий способствует также образование катионами комплексов, в состав сольватной сферы которых входят молекулы полиэтиленгликоля [24].

\section{Выводы}

Таким образом, использование спектров ЭПР солей парамагнитных катионов открывает широкие возможности для оценки гиперконцентрирования ].
Параметры спектров ЭПР $\mathrm{Mn}^{2+}$ при $-180^{\circ} \mathrm{C}$

$\mathrm{Mn}^{2+}$ EPR spectra parameters at $-180^{\circ} \mathrm{C}$

\begin{tabular}{|c|c|c|}
\hline $\begin{array}{l}\text { Растворитель } \\
\text { Solvent }\end{array}$ & $\begin{array}{c}\text { Расщепление главных } \\
\text { линий в направлении от } \\
\text { низкого к высокому } \\
\text { магнитному полю, Гс } \\
\text { Splitting of principal } \\
\text { lines in direction from } \\
\text { low magnetic field to } \\
\text { high one, Gs }\end{array}$ & $\begin{array}{c}\text { Расщепление } \\
\text { дублетов в } \\
\text { направлении от } \\
\text { низкого к высокому } \\
\text { полю }(\Delta \mathrm{H}), \text { Гc } \\
\text { Splitting of doublets in } \\
\text { direction from low } \\
\text { magnetic field to high } \\
\text { one }(\Delta \mathrm{H}), \mathrm{Gs}\end{array}$ \\
\hline $\begin{array}{l}2,8 \text { М ПЭГ-300 } \\
2.8 \text { М PEG-300 }\end{array}$ & $90,92,95,98,100 \pm 2$ & $19,21,22,24 \pm 2$ \\
\hline $\begin{array}{c}\text { Метиловый спирт } \\
\text { Methanol }\end{array}$ & $93,95,96,98,100 \pm 2$ & $22,24,24,26 \pm 2$ \\
\hline $12 \mathrm{M} \mathrm{HCl}$ & $87,88,90,90, \quad 92 \pm 2$ & $19,20,24,23 \pm 2$ \\
\hline
\end{tabular}

Примечание: Расщепление дублетов, рассчитанное по формуле (3) для образца, который содержит ПЭГ-300, составило - $(23 \pm 1)$ Гс, метилового спирта и $12 \mathrm{M} \mathrm{HCl} \mathrm{получены} \mathrm{Allen} \mathrm{B.T.} \mathrm{[18].}$

Note: Doublet splitting calculated by the formula (3) for the samples containing PEG-300, methyl alcohol and $12 \mathrm{M} \mathrm{HCl}$ were $(23 \pm 1),(24 \pm 1)$ and $(21 \pm 1) \mathrm{Gs}$, respectively. Data for methyl alcohol and $12 \mathrm{M} \mathrm{HCl}$ were obtained by Allen B.T.

cond one, as well as a possible existence of following hydrate spheres, the resistance of which decreased with their number augmentation [25]. The presence of such a hydrated coat in strongly diluted solutions pre-vents the cation approaching close enough, thereby reduces the efficiency of intermolecular relationship. In this case the shape of EPR spectra is mostly determined by relaxation effects in liquid systems and is virtually independent on dilution within the salt concentration range from 0.001 to 0.1 . The intermolecular spin-spin interactions, modulated up to a complete solidification of system by a forward motion of liquid particles, are strengthened as a result of salt concentration in the rest liquid areas during freezing of salt aqueous solutions. Such a strengthening of intermolecular coupling between paramagnetic centers results in a significant change of EPR spectra. Fine and hyperfine structures are manifested in frozen aqueous-polyethylene glycol salt solutions in EPR spectra, that suggests a significant decrease in dipole-dipole interactions between paramagnetic centers due to a large distance between them in a solid matrix. The complexes formed by cations, a solvate sphere of which comprises polyethylene glycol molecules, contribute to a decreased interactions as well [13].

\section{Conclusions}

Thus, the use of EPR spectra of paramagnetic cation salts opens wide possibilities to assess hyper- 
солевых растворов при использовании различных режимов замораживания и составов среды замораживания. Представлено описание полученных спектров в терминах спин-гамильтониана. В описании при стеклообразных состояниях замороженных растворов рассматриваются только переходы $M=1 / 2 \leftrightarrow M=-1 / 2$ с проявлением запрещенных пере-ходов $\Delta m= \pm 1$. Полученные результаты могут быть использованы при разработке низкотемпературных технологий консервирования биологических объектов, выборе режимов замораживания и криопротекторов, а также для прогнозирования минимизации эффектов гиперконцентрирования.

\section{Литература}

1. Вишневская Г. П., Гумеров Ф.М., Ягфаров М.Ш. Изучение фазового состава замороженных водных растворов нитрата $\mathrm{Mn}(\mathrm{II})$ методами динамической калориметрии и электронного парамагнитного резонанса // Журнал физической химии. - 1979. - Т. 52, №3. - С. 609-612.

2. Вишневская Г.П., Гумеров Ф.М. Особенности межмолекулярных взаимодействий в водных растворах нитрата хрома // Журнал фриз. химии. - 1981. - Т. 55, №4. - С. 955957.

3. Вишневская Г.П., Фролова Е.Н., Первова И.Т. и др. Комплексы CU (II) с гетарилформазанами в растворах и ионообменных полимерах // Структура и динамика молекулярных систем. - 2003.- Вып. 10 - С. 190-195.

4. Волков В.Я., Сахаров Б.В., Волкова Л.А. Радиоспектроскопические методы в криобиологии // Криобиология. 1985. - №4. - С. 3-10.

5. Волков В.Я., Сахаров Б.В., Волкова Л.А. Природа повреждения и гибели бактерий Francisella tularensis при медленном замораживании // Криобиология. -1991. №4. - C. 10-16.

6. Гарифьянов Н.С., Тимеров Р.Х., Усачева Н.Ф. ЭПР в переохлажденных растворах содержащих ионы $\mathrm{Mn}^{2+}$ и $\mathrm{Gd}^{3+} / /$ Физика твердого тела. - 1962. - Т. 4, Вып. 11. - С. 33443345.

7. Гатауллин А.М. Комплексный релаксационный контроль контрастных веществ для магнитной томографии : Автореф. дис. ... канд. техн. наук. - Казань, 2004. -25 с.

8. Гордиенко Е.А., Пушкарь Н.С. Физические основы низкотемпературного консервирования клеточных суспензий К. : Наук. думка, 1994. - 144 с.

9. Катюхин В.А. Исследование процесса и разработка оборудования для получения замороженных гранул из жидких пищевых продуктов: Автореф. дис. ... канд. техн. наук. M., 1973. -24 c.

10.Ларин Г.М., Шульгин В.Ф., Мельникова Е.Д. и др. Исследование методом ЭПР слабых обменных взаимодействий в биядерных комплексах меди (II) с ацилдигидразонами фторированных $\beta$-дикетонов // Известия РАН. Серия химическая. - 2002. - №4. - С. 585-589.

11.Моисеев В.А., Зинченко В.Д., Нардид О.А. О некоторых молекулярных механизмах криозащиты биологических объектов // Физико-химические процессы в криобиологических системах. - Харьков, 1991. - С. 78-92.

12.Нардід О.А. Внутрішньо- і міжмолекулярні взаємодії та їх роль у кріопошкодженні й кріозахисті біологічних структур: Автореф. дис. ... доктора. біол. наук. - Харків, 2012. - 42 с.

13.Пушкарь Н.С., Белоус А.М. Введение в криобиологию - К.: Наук. думка, 1975. - 344 с concentration of salt solutions when using different freezing regimens and medium compositions. The description of the obtained spectra in spin-Hamiltonian terms is presented. In the description under vitreous states of frozen solutions there are considered only transitions $M=1 / 2 \leftrightarrow M=-1 / 2$ with manifestation of forbidden transitions $\Delta m= \pm 1$. The results obtained may be used in developing low temperature technologies for biological objects preservation, in selecting freezing regimens and cryoprotectants, as well as to forecast the minimization of hyperconcentration effects.

\section{References}

1. Allen B.T. Zero-field splitting parameter of $\mathrm{Mn}^{++}$ion glassy and in polycrystalline media. J Chem Phys 1964; 43(11): 38203826.

2. Allen B.T., Nebert D.W. Hyperfine structure in EPR spectrum of the manganous ion in frozen solutions. J Chem Phys 1964; 41(7): 1983-1985.

3. Garifianov N.S., Timerov R.Kh., Usacheva N.F. EPR in $\mathrm{Mn}^{2+}$ and $\mathrm{Gd}^{3+}$ ions-contained overcooled solutions. Fizika Tverdogo Tela 1962; 4(11): 3344-3345.

4. Gataullin A.M. Combined relaxation control of contrast substances for magnetic tomography [dissertation]. Kazan; 2004.

5. Gordienko E.A., Pushkar N.S. Physical grounds of low temperature preservation of cell suspensions. Kiev: Naukova dumka; 1994.

6. Katyukhin V.A. Study of the process and design of the equipment for obtaining frozen granules from fluid foods [dissertation]. Moscow; 1973.

7. Larin G.M., Shulgin V.F., Melnikova E.D et al. Study by EPR method of weak exchange interactions in copper (II) binuclear complexes with acyldihydrazones of fluorated $\beta$-diketones. Bull Rus Acad Sci. Chemistry series 2002; (4): 585-589.

8. Lovelock J.I. The haemolysis of human red blood cells by freezing and thawing. Biochim Biophys Acta 1953; 10(4): 414-420.

9. Lovelock J.I. The denaturation of lipid/protein complexes as cause of damage by freezing. Proc Roy Soc Ser 1957; 147(4): 427-433.

10.Mazur P. Physical and chemical basis of injury in single celled microorganisms subjected to freezing and thawing. In: G.L. Rapartz, L.J. Menz, B.J. Luyet, H.T. Meryman, editors. Cryobiology. New York: Academic Press; 1966.p. 213-315.

11.Mazur $P$. Kinetics of water loss from cells at sub-zero temperatures and the likelihood of intracellular freezing. J Gen Physiol 1963; 47(2): 347-369.

12.Mazur P., Leibo S, P., Chu E. H. Y. A two-factor hypothesis of injury. Exp Cell Res 1972; 71(2): 345-355.

13.Moiseyev V.A., Nardid O.A., Belous A.M. On a possible mechanism of the protective action of cryoprotectants. CryoLetters 1982; 3(1): 17-26.

14.Moiseyev V.A., Zinchenko V.D., Nardid O.A. About certain molecular mechanisms of cryoprotection of biological objects. In: Physical and chemical processes in cryobiological systems. Kharkov; 1991. p. 78-92.

15.Munzarova M.L., Kubacek P., Kaupp M. Mechanisms of EPR hyperfine coupling in transition metal complexes. J Amer Chem Soc 2000; 122(48): 11900-11913.

16.Nardid O.A. Intra- and intermolecular interactions and their role in cryoinjury and cryoprotection of biological structures [dissertation]. Kharkiv; 2012. 
14. Пушкарь Н.С., Белоус А.М., Иткин Ю.А. и др. Низкотемпературная кристаллизация в биологических системах. К.: Наук. думка, 1975. - 244 с.

15.Розанова Е.Д., Моисеев В.А., Науменко Е.И. Влияние замораживания-отогрева на структуру и функцию цитохромоксидазы // Укр. биохим. журнал. - 1985. - Т. 57, №1. С. 61-64.

16.Шварценбах Г., Флашка Г. Комплексонометрическое титрование. - М.: Химия, 1970. - 360 с.

17.Allen B.T. Zero-field splitting parameter of $\mathrm{Mn}^{++}$ion glassy and in polycrystalline media // J. Chem. Phys. - 1964. - Vol. 43, №11. - P. 3820-3826.

18.Allen B.T., Nebert D.W. Hyperfine structure in EPR spectrum of the manganous ion in frozen solutions // J. Chem. Phys. 1964. - Vol. 41, №7. - P. 1983-1985.

19.Lovelock J.I. The haemolysis of human red blood cells by freezing and thawing // Biochim. Biophys. Acta. - 1953. Vol. 10, №4. - P. 414-420.

20.Lovelock J.I. The denaturation of lipid/protein complexes as cause of damage by freezing // Proc. Roy Soc. Ser. - 1957. Vol. 147, №4. - P. 427-433.

21.Mazur P. Physical and chemical basis of injury in single celled microorganisms subjected to freezing and thawing // Cryobiology / Ed. By G.L. Rapartz, L.J. Menz, B.J. Luyet, H.T. Meryman. - New York: Academic Press, 1966.- P. 213-315.

22. Mazur P. Kinetics of water loss from cells at sub-zero temperatures and the likelihood of intracellular freezing // J. Gen. Physiol. - 1963. - Vol. 47, №2. - P. 347-369.

23.Mazur P., Leibo S, P., Chu E. H. Y. A two-factor hypothesis of injury // Exp. Cell. Res. - 1972. - Vol. 71, №2. - P. 345-355.

24.Moiseyev V.A., Nardid O.A., Belous A.M. On a possible mechanism of the protective action of cryoprotectants // CryoLetters. - 1982. - Vol. 3, №1. - P. 17-26.

25.Munzarova M.L., Kubacek P., Kaupp M. Mechanisms of EPR hyperfine coupling in transition metal complexes // J. Amer. Chem. Soc. - 2000. - Vol. 122, №48. - P. 11900-11913.

26.Rapartz G.L., Menz L.J., Luyet B.J. Anatomy of the freezing process in biological materials // Cryobiology / Ed. By G.L. Rapartz, L.J. Menz, B.J. Luyet, H.T. Meryman. - New York: Academic Press, 1966. - P. 115-137.

27.Sarciaux J.M., Mansour S., Hageman M.J., Nail S.L. Effect of buffer composition and processing conditions on aggregation of bovine IgG during freeze-drying // J. Pharm. Sci. - 1999. Vol. 88, №2. - P. 1354-1361.

28.Silvares O.M., Cravalcho F.G., Toscano W.M. et al. The thermodynamics of water transport for biological cell during freezing // J. Heat Transfer. - 1975. - Vol. 97. - P. 582-588.
17.Pushkar N.S., Belous A.M. Introduction in cryobiology. Kiev: Naukova dumka; 1975.

18. Pushkar N.S., Belous A.M., Itkin Yu.A. et al. Low temperature crystallisation in biological systems. Kiev: Naukova dumka; 1975.

19.Rapartz G.L., Menz L.J., Luyet Â.J. Anatomy of the freezing process in biological materials. In: G.L. Rapartz, L.J. Menz, B.J. Luyet, H.T. Meryman, editors. Cryobiology. New York: Academic Press; 1966. p. 115-137.

20.Rozanova E.D., Moiseyev V.A., Naumenko E.I. Effect of freezethawing on the structure and function of cytochrome oxidase. Ukr Biokhim Zhurn 1985; 57(1): 61-64.

21.Sarciaux J.M., Mansour S., Hageman M.J., Nail S.L. Effect of buffer composition and processing conditions on aggregation of bovine IgG during freeze-drying. J Pharm Sci 1999; 88(2): 1354-1361.

22.Shvartsenbakh G., Flashka G. Complexometric titration. Moscow: Khimiya; 1970.

23.Silvares O.M., Cravalcho F.G., Toscano W.M. et al. The thermodynamics of water transport for biological cell during freezing. J Heat Transfer 1975; 97: 582-588.

24.Vishnevskaya G.P., Gumerov F.M., Yagfarov M.Sh. Study of the phase composition of frozen aqueous solutions of Mn (II) nitrate by the methods of dynamic colorimetry and electron paramagnetic resonance. Zh Fiz Khim 1979; LII(3): 609-612.

25.Vishnevskaya G.P., Gumerov F.M. Characteristics of intermolecular reactions in aqueous solutions of chromium nitrate. Zh Fiz Khim 1981; I.LY(4): 955-957.

26. Vishnevskaya G.P., Frolova E.N., Pervova I.T. et al. Complexes of $\mathrm{Cu}(\mathrm{II})$ with hetarylformazanes in solutions and ion-exchange polymers. Structure and dynamics of molecular systems 2003; X: 190-195.

27.Volkov V.Ya, Sakharkov B.V., Volkova L.A. Radio spectroscopic methods in cryobiology. Kriobiologia 1985; (4): 3-10.

28. Volkov V.Ya, Sakharkov B.V., Volkova L.A. Nature of damages and death of Francisella Tularensis bacteria during slow freezing. Kriobiologia 1991; (4): 10-16. 